\title{
Effects of the phenological stage, cutting type and plant growth regulators on propagation with stem cuttings of Poiretia latifolia Vogel, a Brazilian native medicinal plant
}

\author{
Efectos de la etapa fenológica, tipo de corte y reguladores \\ del crecimiento vegetal en la propagación por corte del tallo \\ de Poiretia latifolia Vogel, una planta medicinal nativa de Brasil
}
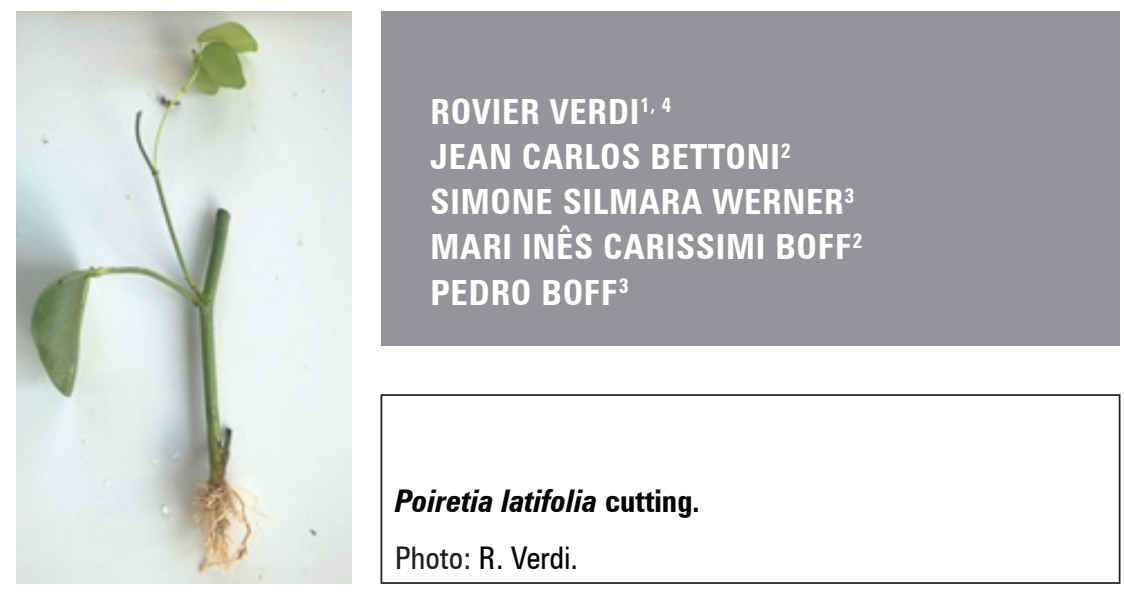

ROVIER VERDI 1,4

JEAN CARLOS BETTONI ${ }^{2}$

SIMONE SILMARA WERNER ${ }^{3}$

MARI INÊS CARISSIMI BOFF²

PEDRO BOFF

\section{Poiretia latifolia cutting.}

Photo: R. Verdi.

\begin{abstract}
Poiretia latifolia Vogel has bioactive potential that includes antibiotic properties for humans. The aim of this research was to develop an efficient method for the vegetative propagation of P. latifolia with cuttings to aid the selection and multiplication of interesting genotypes. In the first experiment, the cuttings were collected in vegetative and reproductive stages and treated with six plant growth regulators and distilled water. In the second experiment, the treatments consisted of cuttings from the apical, median, and basal branch segments. The treatment that immersed cuttings in $4,000 \mathrm{mg} \mathrm{L}^{-1}$ of IBA provided a greater number and length of the roots, while the high dilution of Calcarea phosphorica at $20 \mathrm{CH}$ produced longer branches. The cuttings from the middle and basal part of the branches were more viable. $79.17 \%$ rooting of the cuttings was achieved with Calcarea phosphorica $20 \mathrm{CH}$. The vegetative propagation employed in this study is a feasible option for the domestication, preservation, and cultivation of Poiretia latifolia.
\end{abstract}

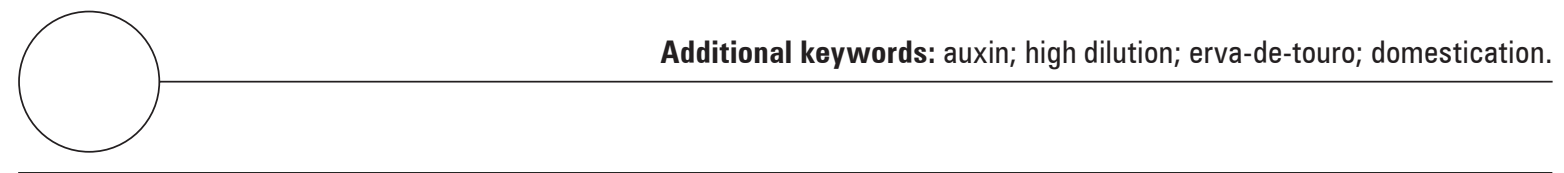

Santa Catarina State University, Post Graduate Program in Plant Production, Lages (Brazil); Coventry University, Centre for Agroecology, Water and Resilience, Coventry (UK). ORCID Verdi, R.: 0000-0002-1120-9665

2 Santa Catarina State University, Post Graduate Program in Plant Production, Lages (Brazil). ORCID Bettoni, J.C.: 0000-0002-7515-9636; ORCID Boff, M.I.C.: 0000-0003-1700-8837

3 Agricultural Research and Rural Extension Agency of Santa Catarina State (EPAGRI), Laboratory of Plant Health and Homeopathy, Lages (Brazil). ORCID Werner, S.S.: 0000-0002-3973-4605; ORCID Boff, P.: 0000-0002-9041-5503

4 Corresponding author. rovierverdi@hotmail.com 


\section{RESUMEN}

Poiretia latifolia Vogel tiene un potencial bioactivo que incluye propiedades antibióticas para usos humanos. El objetivo de esta investigación fue desarrollar un método eficiente para la propagación vegetativa de P. latifolia utilizando esquejes como ayuda para la selección y multiplicación de genotipos interesantes. En el primer experimento, los esquejes se recolectaron en etapas vegetativas y reproductivas y se trataron con seis reguladores del crecimiento vegetal y agua destilada. En el segundo experimento, los tratamientos consistieron en estacas de rama apical, mediana y basal. El tratamiento con la inmersión de esquejes en 4,000 $\mathrm{mg} \mathrm{L}^{-1}$ de IBA proporcionó un mayor número y longitud de las raíces, mientras que la alta dilución de Calcarea phosphorica a 20 CH produjo ramas más largas. Se encontró que los esquejes de la parte media y basal de la rama eran más viables. Se logró el 79,17\% de los esquejes de enraizamiento utilizando Calcarea phosphorica 20 CH. La propagación vegetativa empleada en este trabajo es una opción factible para la domesticación, preservación y cultivo de Poiretia latifolia.

Palabras clave adicionales: auxina; alta dilución; erva-de-touro; domesticación.

Received for publication: 26-04-2020 Accepted for publication: 11-06-2020

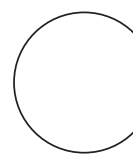

INTRODUCTION

Poiretia latifolia Vogel (Fabaceae), popularly known as "erva-de-touro", is traditionally used in the treatment of stomach and urinary problems, for flavoring traditional yerba mate and as an aphrodisiac (Müller, 1984; Amorim and Boff, 2009). Nanoemulsion, based on its essential oil, has potential as an antidermatophyte and anti-inflammatory agent (Porto et al., 2010; Pérez-Zamora et al., 2016; Paim et al., 2018). In addition, Poiretia latifolia could be an alternative income for farmers since its essential oil is rich in components that are important to the flavour and fragrance industry, such as carvone, dihydrocarvone, and limonene (Porto et al., 2010; Fernandes and Boff, 2017).

Poiretia latifolia naturally occurs on the South Plateau of Santa Catarina, Southern Brazil in the Ombrofila Mista Forest (Fernandes and Boff, 2017). The plant diversity of this region has the potential for numerous uses, for example, grazing, food, medicinal and cosmetic uses. However, this potential has been threatened by anthropogenic activities, such as cattle, fruit orchards, intensive cultivation of soybean and corn, and reforestation with Pinus sp. and Eucalyptus sp. (Pereira et al., 2006; Zank and Hanazaki, 2012). In order to strengthen plant diversity and enhance its potential, the most appropriate propagation technique for plants such as Poiretia latifolia is essential (Nogueira and Nogueira-Filho, 2011; Sarasan et al., 2011; Vodouhè et al., 2011).
Poiretia latifolia seeds have a germination rate above $80 \%$; however, its production is severely damaged by insects, which destroy $54 \%$ of its flowers and $88 \%$ of its seeds (Maass et al., 2018). Vegetative propagation could overcome this problem and even facilitate the selection of the best plant characteristics (Rasmussen et al., 2015; Kaviani and Nagahdar, 2017; Wetzstein et al., 2018). However, vegetative propagation knowledge for P. latifolia is limited and unsuccessful (Teixeira et al. 2011; Amorim et al., 2012). The success of this technique relies on adventitious rooting, which is influenced by several factors, such as plant phenological stage, cutting type and levels of inhibitors and/or promoters of plant growth in the propagule (Guo et al., 2009; Zerche and Druege, 2009; LudwigMüller, 2011; Pacurar et al., 2014; Pigatto et al., 2018).

Exogenous plant growth regulators are widely used in vegetative propagation and can be synthetic or natural. However, when working with medicinal plants, natural alternatives are preferable. Yamashita et al. (2017) found that Cyperus rotundus extract (natural) and indol-3-butiric acid - IBA (synthetic) improved the rooting of Myrciaria cauliflora and Psidium guajava cuttings. High dilutions are another alternative that aid production, minimizing residues and reducing costs (Moreno, 2017). The homeopathic preparations Phosphorus $3 \mathrm{CH}$ and Kali muriaticum $12 \mathrm{CH}$, selected based on the nutrients commonly used in plant fertilization, promoted increased root growth 
in eucalyptus seedlings. (Moraes et al., 2018). Cassol et al. (2017) also reported that the use of IBA and Arnica montana $12 \mathrm{CH}$ stimulated the rooting of Cuphea gracilis.

The objective of this study was to evaluate the influence of phenological stages, segments of the branch and plant growth regulators on the vegetative propagation of $P$. latifolia using stem cutting.

\section{MATERIALS AND METHODS}

\section{Collection and conduction locations}

This study was conducted at the Lages Experimental Station of the EPAGRI (Agricultural Research and Rural Extension Agency of Santa Catarina State, Brazil). The vegetative material used in the experiments was collected from a natural population of Poiretia latifolia in the region of Vacas Gordas, district of Capão Alto, Santa Catarina (27'58'33.1" S and 50'30'26.5" W). Immediately after the sampling, the herbaceous shoots were immersed in water and transported in polystyrene boxes to avoid dehydration of the vegetal material.

\section{Experiment design}

In the first experiment, seven treatments with plant growth regulators were evaluated: immersion of the base of the cuttings for $20 \mathrm{~s}$ in four concentrations of indole-3-butyric acid (IBA) $(1,000,2,000,3,000$, and $\left.4,000 \mathrm{mg} \mathrm{L}^{-1}\right)$; aqueous extract of Cyperus rotundus, $10 \%$ concentration; high dilution of Calcarea phosphorica at $20 \mathrm{CH}(\mathrm{CH}=$ hahnemannian centesimal dilution order); and pure water (control). Each treatment had three replicates of 20 cuttings in a completely randomized block design. The experiment was carried out in both phenological stages of $P$. latifolia: vegetative (14 December, 2016) and reproductive (18 January, 2017). In total, 840 cuttings were used in the experiment.

In the second experiment, the treatments consisted of the cutting type in terms of the segment of the $P$. latifolia branch, divided into the basal, median, and apical thirds. Each treatment had four replicates of 20 cuttings in a randomized block design, totaling 240 cuttings in the experiment. The cuttings were collected at the reproductive stage (22 February, 2017).

\section{Obtaining and applying plant growth regulators}

The IBA was dissolved in $1 \mathrm{~N} \mathrm{NaOH}$ and adjusted to the concentrations with distilled water. The aqueous extract of Cyperus rotundus was obtained by blending $100 \mathrm{~g}$ of fresh plant bulbs in 1,000 $\mathrm{mL}$ of pure water in a blender for $10 \mathrm{~min}$. The high dilution of Calcarea phosphorica was obtained from a pharmacy, and the last two levels of dynamization were made with pure water, following the methodology described in the Brazilian Homeopathic Pharmacopoeia (2011). The plant growth regulators were applied with immersion for $20 \mathrm{~s}$ with $1 / 3$ of the base of the cuttings in the solution. The high dilution of Calcarea phosphorica at $20 \mathrm{CH}$ was applied to the aerial part of the cuttings with spraying twice a week at a volume of $50 \mathrm{~mL}$ per replicate until the end of the experiment. During this period, the other treatments received pure water.

\section{Cutting preparation and planting}

The herbaceous $P$. latifolia shoots were segmented into cuttings with two lateral buds. In the first experiment, all branch segments were used and placed randomly inside the blocks, producing cuttings with varied lengths and diameters. In the second experiment, the diameter and length of the cuttings varied according to the characteristics of the segment evaluated: basal, median, or apical.

The preparation of the cuttings for all experiments and treatments followed the protocol described by Bettoni et al. (2014b). At the base of the cuttings, a transverse cut was made, with $20 \%$ of the total length of the cutting remaining below the lateral bud. At the top end of the cutting, an angle cut was made, with $30 \%$ of the total length of the cutting remaining above the lateral bud. Afterwards, at the base of the cuttings, two longitudinal lesions were made, with approximately $30 \%$ of the total length of the cuttings. A leaflet was maintained on each cutting.

After preparation, the cuttings were transplanted to Styrofoam honeycomb trays with 60 cells with sand and vermiculite substrate $(1: 1, \mathrm{v} / \mathrm{v})$. The trays were arranged in plastic boxes $(60 \times 40 \times 20 \mathrm{~cm})$ and covered with a transparent plastic film to maintain moisture saturation. They were watered with spraying twice per day and kept in a greenhouse at $25^{\circ} \mathrm{C}$. No control for pests and diseases was carried out. 


\section{Statistical analysis and assessment}

Survival rate, rooting rate, shoot sprouting rate, number of roots and shoots, and length of the four larger roots and the two larger shoots were assessed $35 \mathrm{~d}$ after planting the cuttings. In order to analyze survival, rooting, and sprouting, generalized linear models were used with the binomial model or the binomial model with a dispersion parameter (quasibinomial), both considering the logit link function. The means were compared with confidence intervals (95\%) for Tukey contrasts of the linear predictors of the fitted model. All analyses were performed using the R environment v 3.2.1 (The R Foundation, 2015).

\section{RESULTS AND DISCUSSION}

The joint analysis of the experiment with plant growth regulators in the vegetative and reproductive phases of $P$. latifolia plants showed the simple effect of the treatments (Tab. 1), meaning that the plant growth regulators performed similarly in the two phenological stages: vegetative and reproductive.

The phenological stage of the P. latifolia plants influenced the cutting viability through the rate of surviving, rooting, and sprouted cuttings; the vegetative stage was the lowest (Tab. 2). The plant growth regulators did not increase the cuttings viability. Cuttings

Table 1. Descriptive levels (p-values) of the joint analysis of propagation with Poiretia latifolia cuttings and plant growth regulators in the vegetative and reproductive stages, Lages, SC, 2018.

\begin{tabular}{|l|r|r|r|r|r|r|c|}
\hline Factors & SURV. & R & R/C & LR & S & S/C & LS \\
\hline PE & $<0.0001$ & $<0.0001$ & $<0.0001$ & $<0.0001$ & $<0.0001$ & 0.0430 & 0.3806 \\
\hline PE/Block & 0.0371 & 0.0230 & 0.1738 & 0.0085 & 0.0352 & 0.7835 & 0.1011 \\
\hline GR & 0.0417 & 0.0293 & $<0.0001$ & $<0.0001$ & 0.0369 & 0.0438 & 0.0069 \\
\hline GR ${ }^{*}$ PE & 0.0724 & 0.0699 & 0.6407 & 0.5178 & 0.1897 & 0.9826 & 0.2279 \\
\hline
\end{tabular}

$\mathrm{PE}=$ phenological stage, $\mathrm{GR}=$ growth regulators, $S U R V$. = survival rate of cuttings, $\mathrm{R}=$ rooting rate, $\mathrm{R} / \mathrm{C}=$ roots per cutting, $\mathrm{LR}=$ mean length of the four largest roots, $S=$ sprouting rate, $S / C=$ shoots per cuttings, $L S=$ mean length of the two largest shoots.

Table 2. Viability of Poiretia latifolia cuttings collected in different phenological stages, treated with plant growth regulators and from different sections of the branch. Lages, SC, 2018.

\begin{tabular}{|c|c|c|c|}
\hline Treatments & Survival (\%) & Rooting (\%) & Sprouting (\%) \\
\hline \multicolumn{4}{|c|}{ Phenological stages of plant collection ${ }^{1}$} \\
\hline Vegetative & $53.81 \pm 3.16 b$ & $55.71 \pm 3.01 b$ & $49.52 \pm 3.25 b$ \\
\hline Reproductive & $81.90 \pm 2.22 \mathrm{a}$ & $82.62 \pm 2.09 \mathrm{a}$ & $70.00 \pm 2.50 \mathrm{a}$ \\
\hline \multicolumn{4}{|c|}{ Plant growth regulators ${ }^{1}$} \\
\hline Control & $68.33 \pm 5.43 a b$ & $68.33 \pm 5.11 \mathrm{ab}$ & $60.83 \pm 3.52 \mathrm{ab}$ \\
\hline $1,000 \mathrm{mg} \mathrm{L}^{-1} \mathrm{IBA}$ & $57.50 \pm 9.20 \mathrm{~b}$ & $58.33 \pm 8.63 b$ & $47.67 \pm 8.82 \mathrm{~b}$ \\
\hline $2,000 \mathrm{mg} \mathrm{L}^{-1} \mathrm{IBA}$ & $66.67 \pm 8.72 a b$ & $70.00 \pm 8.66 \mathrm{ab}$ & $63.33 \pm 8.23 \mathrm{ab}$ \\
\hline $3,000 \mathrm{mg} \mathrm{L}^{-1} \mathrm{IBA}$ & $64.17 \pm 7.46 a b$ & $67.50 \pm 6.42 a b$ & $60.83 \pm 8.41 \mathrm{ab}$ \\
\hline $4,000 \mathrm{mg} \mathrm{L}^{-1} \mathrm{IBA}$ & $72.50 \pm 6.68 \mathrm{ab}$ & $74.17 \pm 7.00 \mathrm{ab}$ & $60.00 \pm 4.83 \mathrm{ab}$ \\
\hline C. rotundus & $66.67 \pm 10.46 a b$ & $66.67 \pm 9.80 b$ & $64.17 \pm 10.36 \mathrm{ab}$ \\
\hline Calc. phos. $20 \mathrm{CH}$ & $79.17 \pm 5.54 \mathrm{a}$ & $79.17 \pm 5.39 a$ & $72.50 \pm 4.23 \mathrm{a}$ \\
\hline \multicolumn{4}{|c|}{ Sections of the branch ${ }^{2}$} \\
\hline Apical & $2.50 \pm 1.44 b$ & $2.50 \pm 1.44 b$ & $5.00 \pm 0.00 \mathrm{c}$ \\
\hline Median & $16.25 \pm 1.25 \mathrm{a}$ & $32.50 \pm 2.50 \mathrm{a}$ & $17.50 \pm 1.44 \mathrm{a}$ \\
\hline Basal & $12.50 \pm 2.50 \mathrm{a}$ & $46.25 \pm 2.39 \mathrm{a}$ & $12.50 \pm 2.50 b$ \\
\hline
\end{tabular}

Control = distilled water, $\mathrm{C}$. rotundus = aqueous extract of Cyperus rotundus, Calc. phos. $20 \mathrm{CH}=$ High dilution of Calcarea phosphorica at $20 \mathrm{CH}(\mathrm{CH}=\mathrm{Hahneman}$ nian centesimal dilution order). Different letters in the columns present a statistical difference between treatments, Tukey's contrast $(P \leq 0.05)$. Means \pm standard error; ${ }^{1}$ Trials analyzed together; ${ }^{2}$ Independent trial. 
from the medial and basal branch sections performed better than those from the apical section. The sprouting rate was still better for the basal section than for the median section (Tab. 2).

The vegetative stage, contrary to that found for viability (Tab. 2), increased the number of roots, average length of the four larger roots, number of shoots, and average length of the two bigger shoots (Tab. 3).

The IBA concentrations 3,000 and $4,000 \mathrm{mg} \mathrm{L}^{-1}$ had higher root numbers than the treatments without synthetic auxin applications. IBA at $4,000 \mathrm{mg} \mathrm{L}^{-1}$ was superior to $2,000 \mathrm{mg} \mathrm{L}^{-1}$ but did not differ from 3,000 $\mathrm{mg} \mathrm{L}^{-1}$ for the length of the four larger roots (Tab. $3)$. Increases in the IBA concentration increased the number of roots per cutting and the average length of the four larger roots, which had an inverse relationship with the shoot number and the length of the two larger shoots (Tab. 3).

The growth regulators did not influence the number of shoots per cutting. However, Calcarea phosphorica $20 \mathrm{CH}$ increased the length of the two larger shoots of the cuttings but did not differ from the IBA concentrations 1,000 and 2,000 $\mathrm{mg} \mathrm{L}^{-1}$ (Tab. 3). The different branch sections did not differ in the quality of the viable P. latifolia cuttings (Tab. 3).

During the plant collection, the branches were more lignified in the reproductive stage than in the vegetative stage. Cuttings from older plants that are more lignified, besides having more nutrient reserves because of the tissue consistency, are more resilient to environmental stresses, such as temperature and humidity (Villa et al., 2017). This may explain the better cutting viability for the reproductive stage and the medial and basal branch segments of $P$. latifolia plants (Tab. 2).

However, the vegetative stage had better cutting quality than the reproductive stage, the opposite of that found for cutting viability. According to Maia et al. (2008), more lignified cuttings may impede rooting, observing better rooting in less lignified cuttings of the apical segment of Hyptis suaveolens branches. Even though lower nutritional reserves and less resistance to stresses impede cutting viability, cuttings from the vegetative stage may have a better hormonal balance, improving rooting quality in surviving cuttings (Ludwig-Müller, 2011; Pacurar et al., 2014).

Table 3. Quality of viable Poiretia latifolia cuttings collected in different phenological stages, treated with plant growth regulators and from different sections of the branch. Lages, SC, 2018.

\begin{tabular}{|c|c|c|c|c|}
\hline Treatments & $R / C\left(n^{\circ}\right)$ & $\mathrm{LR}(\mathrm{cm})$ & $S / C\left(n^{\circ}\right)$ & $\mathrm{LS}(\mathrm{cm})$ \\
\hline \multicolumn{5}{|c|}{ Phenological stages of plant collection ${ }^{1}$} \\
\hline Vegetative & $21.46 \pm 0.82 \mathrm{a}$ & $18.39 \pm 0.65 \mathrm{a}$ & $1.35 \pm 0.06 \mathrm{a}$ & $8.18 \pm 0.46 a$ \\
\hline Reproductive & $16.77 \pm 0.63 b$ & $15.67 \pm 0.49 b$ & $1.19 \pm 0.04 b$ & $7.78 \pm 0.32 b$ \\
\hline \multicolumn{5}{|c|}{ Plant growth regulators ${ }^{1}$} \\
\hline Control & $16.97 \pm 1.35 b c$ & $15.35 \pm 1.22 b$ & $1.25 \pm 0.10 \mathrm{ab}$ & $7.59 \pm 0.43 b$ \\
\hline $1,000 \mathrm{mg} \mathrm{L}^{-1} \mathrm{IBA}$ & $19.58 \pm 1.24 a b c$ & $17.46 \pm 1.14 \mathrm{ab}$ & $1.27 \pm 0.11 \mathrm{ab}$ & $8.04 \pm 0.71 \mathrm{ab}$ \\
\hline $2,000 \mathrm{mg} \mathrm{L}^{-1} \mathrm{IBA}$ & $20.90 \pm 1.26 a b$ & $17.57 \pm 0.41 b$ & $1.31 \pm 0.08 \mathrm{ab}$ & $8.27 \pm 0.79 a b$ \\
\hline $3,000 \mathrm{mg} \mathrm{L}^{-1} \mathrm{IBA}$ & $22.47 \pm 1.54 \mathrm{a}$ & $17.66 \pm 0.94 \mathrm{ab}$ & $1.07 \pm 0.09 b$ & $6.81 \pm 0.67 b$ \\
\hline $4,000 \mathrm{mg} \mathrm{L}^{-1} \mathrm{IBA}$ & $21.63 \pm 1.42 \mathrm{a}$ & $20.46 \pm 1.07 \mathrm{a}$ & $1.10 \pm 0.06 \mathrm{ab}$ & $6.79 \pm 0.52 b$ \\
\hline C. rotundus & $15.83 \pm 1.81 \mathrm{c}$ & $14.16 \pm 1.37 b$ & $1.40 \pm 0.07 \mathrm{ab}$ & $8.13 \pm 0.68 b$ \\
\hline Calc. phos. $20 \mathrm{CH}$ & $16.42 \pm 1.14 \mathrm{c}$ & $16.58 \pm 0.61 b$ & $1.52 \pm 0.11 \mathrm{a}$ & $10.26 \pm 0.67 a$ \\
\hline \multicolumn{5}{|c|}{ Sections of the branch ${ }^{2}$} \\
\hline Apical & $4.00 \pm 2.00 \mathrm{a}$ & $11.90 \pm 9.10 \mathrm{a}$ & $1.00 \pm 0.00 \mathrm{a}$ & $3.00 \pm 2.00 \mathrm{a}$ \\
\hline Median & $7.58 \pm 0.64 a$ & $13.12 \pm 1.76 \mathrm{a}$ & $1.17 \pm 0.10 \mathrm{a}$ & $5.04 \pm 0.83 a$ \\
\hline Basal & $7.37 \pm 1.40 a$ & $9.63 \pm 1.07 \mathrm{a}$ & $1.12 \pm 0.12 \mathrm{a}$ & $3.12 \pm 1.16 \mathrm{a}$ \\
\hline
\end{tabular}

Control $=$ distilled water, $\mathrm{C}$. rotundus $=$ aqueous extract of Cyperus rotundus, Calc. phos. $20 \mathrm{CH}=$ high dilution of Calcarea phosphorica at 20CH $(\mathrm{CH}=\mathrm{Hahne}-$ mannian centesimal dilution order), $R / C=$ roots per cutting, $L R=$ mean length of the four larger roots, $S / C=$ shoots per cuttings, $L S=$ mean length of the two larger shoots. Different letters in the columns present a statistical difference between treatments, Tukey's contrast $(P \leq 0.05)$. Means \pm standard error; ${ }^{1}$ Trials analyzed together; ${ }^{2}$ Independent trial. 
The IBA effects on root quality in this study were also observed by Bettoni et al. (2014a) and Amorim et al. (2012), who observed that, although IBA did not change the cutting viability of grapevine rootstocks and Poiretia latifolia cuttings, it improved the quality of the surviving cuttings. Amorim et al. (2012) suggested that studies on higher IBA concentrations and other rooting inducers. However, the application of IBA or increases its doses does not necessarily promote the quality of cuttings. Benzylaminopurine (BAP) concentrations from 0.2 to $3.0 \mathrm{mg} \mathrm{L}^{-1}$ did not enhance Poiretia latifolia vegetative propagation, and although there was not a statistical difference, the treatment with $2,000 \mathrm{mg} \mathrm{L}^{-1}$ of AIB promoted a better rooting rate than the treatment with $4,000 \mathrm{mg} \mathrm{L}^{-1}$ (Teixeira et al., 2011).

The high dilution of Calcarea phosphorica at $20 \mathrm{CH}$ promoted shoot growth and did not interfere with root quality (Tab. 3). Calcarea phosphorica, when applied at a young age, strengthens plants, improving nutrient absorption and resilience when suffering a hydric stress (Moreno, 2017). However, choosing a high dilution that provides the desired effect is somewhat complex and depends on several factors, such as the preparation method and the potency, application, concentration and nature of the preparation (Hanif and Dawar, 2015; Giesel et al., 2017). Giesel et al. (2017) reported that both the potency and the dynamization method influence the effect of a high dilution on the foraging of leaf-cutting ants (Acromyrmex laticeps Emery). According to Broetto et al. (2011), the quality of seedlings is associated with the development of both the aerial part and roots. Thus, more studies are needed to achieve results similar to that of the study by Pulido et al. (2014), who was able to stimulate both aerial growth and cabbage roots. The homeopathic preparations Phosphorus $3 \mathrm{CH}$ and Kali muriaticum $12 \mathrm{CH}$, selected based on the nutrients commonly used in plant fertilization, promoted increased root growth in eucalyptus seedlings (Moraes et al., 2018). Cassol et al. (2017) also reported that the use of IBA and Arnica montana $12 \mathrm{CH}$, usually used to help an organism cope with traumatic events such the cutting process, stimulated the rooting of Cuphea gracilis.

The results obtained from the $P$. latifolia cuttings treated with C. rotundus extracts were similar to those of Yamashita et al. (2017), who tested five concentrations of the extract $(0,25,50,75$, and $100 \%)$ and did not observe a difference in the number of roots in Myrciaria cauliflora and Psidium guajava. The authors suggested that the auxin concentration in the aqueous extract of $C$. rotundus is not sufficient to increase the number of roots. Dias et al. (2012) also warned that, depending on the cutting immersion time, the extract may have toxicity effects.

Even though there was no increase in the rooting rate with the plant growth regulator treatments, the application of $4,000 \mathrm{mg} \mathrm{L}^{-1}$ of IBA provided better development of the root system in the P. latifolia cuttings. The high dilution of Calcarea phosphorica at $20 \mathrm{CH}$ provided better development of the aerial part of the P. latifolia cuttings. The methodology for the cutting collection and preparation, as well as the conduction period of the rooting, provided a higher rooting rate $(79.17 \%$ ) than in previous studies (around 10 and 40\%) (Amorim et al., 2012; Teixeira et al., 2011).

\section{CONCLUSION}

Calcarea phosphorica achieved a rooting rate of $79.17 \%$. The high dilution improved the aerial part of the $P$. latifolia cuttings, while the AIB enhanced the rooting quality. More studies on these two plant growth regulators, both individually and combined, should be carried out to improve the vegetative propagation of this species. More lignified Poiretia latifolia cuttings are more viable because of the phenological stage and the position of the branch segment. The vegetative propagation used in this study is a feasible option for the domestication, preservation, and cultivation of Poiretia latifolia.

\section{Funding}

This study was supported by the project Rede Guarani/Serra Geral, in partnership with FAPESC [grant number 2015TR1067].

\section{ACKNOWLEDGMENTS}

The authors would like to thank the researchers Dr. Murilo Dalla Costa and Dr. Tássio Dresch Reck, lab technician Elisangela Madruga, as well as the owners of the areas where the collections were made. The first and second authors thank the Office for Improvement of Academic Personnel (CAPES) of the Brazilian Ministry of Education (MEC) for the Scholarship in Brazil and for the second author's Scholarship for Doctoral Sandwich Program Abroad (PDSE) 
in the United States of America. The fourth and fifth authors are also $\mathrm{PQ}-\mathrm{CNPq}$ researchers (process $\mathrm{n}$. 304018/2015 and 307376/2017-6).

Conflict of interests: The manuscript was prepared and reviewed with the participation of the authors, who declare that there exists no conflict of interest that puts at risk the validity of the presented results.

\section{BIBLIOGRAPHIC REFERENCES}

Amorim, C.C. 2009. Ethnobotany of land medicine in the Coxilha Rica region, SC. Rev. Bras. Agroecol. 4(2), 1596-1599.

Amorim, C.C., M.D. Costa, and P. Boff. 2012. Micropropagation and rooting of herbaceous cuttings of Poiretia latifolia Vogel. Agropec. Catarin. 25(3), 54-57.

Bettoni, J.C., J.P. Gardin, R. Schumacher, N.P. Feldberg, J.A. Souza, and C. Furlan. 2014a. Use of IBA improves quality of roots in herbaceous cutting of grapevine rootstocks. Evidência 14(1), 47-56.

Bettoni, J.C., J.P. Gardin, R. Schumacher, J.L. Petri, J.A. Souza, and N. Feldberg. 2014b. Rooting for the stakes rootstock vine vr043-43 under application of lesion and auxins applications. Evidência 14(2), 129-138.

Brazilian Homeopathic Pharmacopoeia. 2011. $3^{\text {rd }}$ ed. In: http://portal.anvisa.gov.br/documents/33832/ $259147 /$ Farmacopeia + HOMEOPATICA + 3a + EDICAO+INGLES + com + alerta.pdf/49a48a500d3e-4ab9-bc41-eb361c8afbb1; consulted: February, 2020 .

Broetto, D., J.O. Baumann, A. Sato, and R. Botelho. 2011. Development and occurrence of ground pearl in vitis grafted on 'VR 043-43' and 'Paulsen 1103' rootstock. Rev. Bras. Frutic. 33, 404-410. Doi: 10.1590/ S0100-29452011000500052

Cassol, D.A., M. Dotto, K. Pirola, A.W. Júnior. 2017. Behavior of piles and indolbutyric or homeopathic prepared acid Arnica montana spread of false-erica. Ornam. Hortic. 23(2), 138-143. Doi: 10.14295/oh.v23i2.945

Dias, J.R.M., E.D.A. Silva, G.S. Gonçalves, J.F. Silva, E.F.M. Souza, E. Ferreira, and R. Stachiw. 2012. Rooting of coffee cuttings immersed in tiririca extract. Coffee Sci. 7(3), 259-266.

Fernandes, P. and P. Boff. 2017. Medicinal plants in the family farms of rural areas in southern Brazil: ecological and ethnobotanical aspects. Bol. Latinoam. Caribe Plant. Med. Aromat. 16(5), 493-505.

Giesel, A., M.I.C. Boff, and P. Boff. 2017. Dynamized high dilutions for management of the leafcutter ant Acromyrmex laticeps Emery (Hymenoptera: Formicidae). Acta. Sci. Agron. 39(4), 497-503. Doi: 10.4025/ actasciagron.v39i4.32848
Guo, X., X. Fu, D. Zang, and Y. Ma. 2009. Effect of auxin treatments, cuttings' collection date and initial characteristics on Paeonia 'Yang Fei Chu Yu' cutting propagation. Sci. Hortic. 19(2), 177-181. Doi: 10.1016/j. scienta.2008.07.022

Hanif, A. and S. Dawar. 2015. Fungicidal effects of homeopathic drugs in the control of root rot fungi and growth of leguminous and non-leguminous crops. Int. J. Biol. Biotechnol. 12(1), 97-105.

Kaviani, B. and N. Negahdar. 2017. Propagation, micropropagation and cryopreservation of Buxus hyrcana Pojark., an endangered ornamental shrub. South Afr. J. Bot. 111, 326-335. Doi: 10.1016/j.sajb.2017.04.004

Ludwig-Müller, J. 2011. Auxin conjugates: their role for plant development and in the evolution of land plants. J. Exp. Bot. 62(6), 1757-1773. Doi: 10.1093/jxb/erq412

Maass, R.M., M.I.C. Boff, J.M. Rosa, and T.G. Pikart. 2018. Entomofauna associated with erva-de-touro (Poiretia latifolia Vogel) stands in the Santa Catarina plateau region. Rev. Ciênc. Agrovet. 17(1), 128-135. Doi: 10.5965/223811711712018128

Maia, S.S., J.E. Pinto, F.N. Silva, and C.D. Oliveira. 2008. Rooting of Hyptis suaveolens (L.) Poit (Lamiaceae) in relation to the position of the cuttings in plant branches. Rev. Bras. Ciênc. Agrár. 3(4), 317-320.

Moraes, L.C.C.A.V., V.W.D. Casali, and J.N.G. Barros. 2018. Increase in growth of eucalyptus seedlings with application of homeopathic preparations. Int. J. H. D. Res. 17(3-4), 58-62.

Moreno, N.M. 2017. Agrohomeopatía como alternativa a los agroquímicos. Rev. Méd. Homeop. 10(1), 9-13. Doi: 10.1016/j.homeo.2017.04.004

Müller, C. 1984. Revisão taxonômica do gênero Poiretia Vent. (Leguminosae) para o Brasil. MSc thesis. Universidade Estadual de Campinas, Campinas, Brazil.

Nogueira, S.S. and S.L. Nogueira-Filho. 2011. Wildlife farming: an alternative to unsustainable hunting and deforestation in Neotropical forests?. Biodivers. Conserv. 20(7), 1385-1397. Doi: 10.1007/s10531-011-0047-7

Pacurar, D.I., I. Perrone, and C. Bellini. 2014. Auxin is a central player in the hormone cross talks that control adventitious rooting. Physiol. Plant. 151(1), 83-96. Doi: 10.1111/ppl.12171

Paim, L.F.N.A., D.F.D. Lana, M. Giaretta, L.J. Danielli, A.M. Fuentefria, M.A. Apel, and I.C. Külkamp-Guerreiro. 2018. Poiretia latifolia essential oil as a promising antifungal and anti-inflammatory agent: Chemical composition, biological screening, and development of a nanoemulsion formulation. Ind. Crops. Product. 126, 280-286. Doi: 10.1016/j.indcrop.2018.10.016

Pereira, J.A., J.F. Neto, O. Ciprandi, and C.E.A. Días. 2006. Local knowledge, modernization, soil use and 
management: an etnopedological study on the southern plateau of Santa Catarina. Rev. Ciênc. Agrovet. 5(2), 140-148.

Pérez-Zamora, C.M., C.A. Torres, M.I. Aguado, A.J. Bela, M.B. Nuñez, and C. Bregni. 2016. Antibacterial activity of essential oils of Aloysia polystachya and Lippia turbinata (Verbenaceae). Bol. Latinoam. Caribe Plant. Med. Aromat. 15(4), 199-205.

Pigatto, G.B., E.N. Gomes, J.C. Tomasi, A.P. Ferriani, and C. Deschamps. 2018. Efectos de ácido indolbutírico, posiciones de estacas de tallo y sustratos sobre la propagación vegetativa de Stevia rebaudiana Bertoni. Rev. Colomb. Cienc. Hortic. 12(1), 202-211. Doi: 10.17584/ rcch.2018v12i1.6631

Porto, C., C.Z. Stüker, A.S. Mallmann, E. Simionatto, A. Flach, T.D. Canto-Dorow, U.F. Silva, I.I. Dalcoll, and A.F. Morel. 2010. (R)-(-)-carvone and (1R, 4R)trans-(+)-dihydrocarvone from Poiretia latifolia Vogel. J. Braz. Chem. Soc. 21(5), 782-786. Doi: 10.1590/ S0103-50532010000500003

Pulido, E.E., P. Boff, T.S. Duarte, and M.I. Boff. 2014. Homeopathic preparations for growth and yield of cabbage in organic system. Hortic. Bras. 32(3), 267-272. Doi: 10.1590/S0102-05362014000300005

Rasmussen, A., S.A. Hosseini, M.R. Hajirezaei, U. Druege, and D. Geelen, 2015. Adventitious rooting declines with the vegetative to reproductive switch and involves a changed auxin homeostasis. J. Exp. Bot. 66(5), 1437-1452. Doi: 10.1093/jxb/eru499

Sarasan, V., G.C. Kite, G.W. Sileshi, and P.C. Stevenson. 2011. Applications of phytochemical and in vitro techniques for reducing over-harvesting of medicinal and pesticide plants and generating income for the rural poor. Plant. Cell. Rep. 30(7), 1163-1172. Doi: 10.1007/s00299-011-1047-5
Teixeira, C.S., C. Amorim, M.D. Costa, M.I.C. Boff, and P. Boff. 2011. Neglected plant species, in vitro and cutting propagation of Poiretia latifolia Vogel. Cad. Agroecol. 6(2), 1-5.

The R Foundation. 2015. A language and environment for statistical computing. http://www. r-project.org; consulted: May, 2019

Villa, F., A.L. Piva, É.J. Mezzalira, and A. Santin. 2017. Cuttings in propagation of gooseberry. Magistra 28(2), 185-193.

Vodouhè, R., A. Dansi, H.T. Avohou, B. Kpèki, and F. Azihou. 2011. Plant domestication and its contributions to in situ conservation of genetic resources in Benin. Int. J. Biodivers. Conserv. 3(2), 40-56.

Wetzstein, H.Y., J.A. Porter, J. Janick, J.F. Ferreira, and T.M. Mutui. 2018. Selection and clonal propagation of high artemisinin genotypes of Artemisia annua. Front. Plant. Sci. 9, 1-11. Doi: 10.3389/fpls.2018.00358

Yamashita, O.M., G.W.P. Azevedo, W.M. Peres, G.Q. David, M.A.C. Carvalho, and P.S. Koga. 2017. Seedling production of fruit and ornamental species to the use of weed hormone (Cyperus rotundus). Nucle 14(1), 279 288. Doi: 10.3738/1982.2278.1988

Zank, S. and N. Hanazaki. 2012. Exploring the links between ethnobotany, local therapeutic practices, and protected areas in Santa Catarina coastline, Brazil. Évid.-based Complement. Altern. Med. 12, 1-15. Doi: $10.1155 / 2012 / 563570$

Zerche, S. and U. Druege. 2009. Nitrogen content determines adventitious rooting in Euphorbia pulcherrima under adequate light independently of pre-rooting carbohydrate depletion of cuttings. Sci. Hortic. 121(3), 340-347. Doi: 10.1016/j.scienta.2009.02.012 